\title{
Role of Parathyroid Hormone in the Glucose Intolerance of Chronic Renal Failure
}

Mohammad Akmal, Shaul G. Massry, David A. Goldstein, Paolo Fanti, Alexandro Weisz, and Ralph A. DeFronzo Division of Nephrology and Department of Medicine, the University of Southern California School of Medicine, Los Angeles, California 90033; and Department of Medicine, Yale University School of Medicine, New Haven, Connecticut 06510

\section{Abstract}

Evidence has accumulated suggesting that the state of secondary hyperparathyroidism and the elevated blood levels of parathyroid hormone (PTH) in uremia participate in the genesis of many uremic manifestations. The present study examined the role of PTH in glucose intolerance of chronic renal failure (CRF). Intravenous glucose tolerance tests (IVGTT) and euglycemic and hyperglycemic clamp studies were performed in dogs with CRF with (NPX) and without parathyroid glands (NPX-PTX). There were no significant differences among the plasma concentrations of electrolytes, degree of CRF, and its duration. The serum levels of PTH were elevated in NPX and undetectable in NPX-PTX.

The NPX dogs displayed glucose intolerance after CRF and blood glucose concentrations during IVGTT were signifcantly $(P<0.01)$ higher than corresponding values before CRF. In contrast, blood glucose levels after IVGTT in NPXPTX before and after CRF were not different. $K-g$ rate fell after CRF from $2.86 \pm 0.48$ to $1.23 \pm 0.18 \% / \mathrm{min}(P<0.01)$ in NPX but remained unchanged in NPX-PTX (from $2.41 \pm 0.43$ to $2.86 \pm 0.86 \% / \mathrm{min}$ ) dogs. Blood insulin levels after IVGTT in NPX-PTX were more than twice higher than in NPX animals $(P<0.01)$ and for any given level of blood glucose concentration, the insulin levels were higher in NPX-PTX than NPX dogs.

Clamp studies showed that the total amount of glucose utilized was significantly lower $(P<0.025)$ in NPX $(6.64 \pm 1.13$ $\mathrm{mg} / \mathrm{kg} \cdot \mathrm{min})$ than in NPX-PTX $(10.74 \pm 1.1 \mathrm{mg} / \mathrm{kg} \cdot \mathrm{min}) \mathrm{dogs}$. The early, late, and total insulin responses were significantly $(P<0.025)$ greater in the NPX-PTX than NPX animals. The values for the total response were $143 \pm 28$ vs. $71 \pm 10 \mu \mathrm{U} / \mathrm{ml}$, $P<0.01$. There was no significant difference in the ratio of glucose metabolized to the total insulin response, a measure of tissue sensitivity to insulin, between the two groups. The glucose metabolized to total insulin response ratio in NPX $(5.12 \pm 0.76 \mathrm{mg} / \mathrm{kg} \cdot \mathrm{min}$ per $\mu \mathrm{U} / \mathrm{ml})$ and NPX-PTX (5.18 \pm 0.57 $\mathrm{mg} / \mathrm{kg} \cdot \mathrm{min}$ per $\mu \mathrm{U} / \mathrm{ml}$ ) dogs was not different but significantly $(P<0.01)$ lower than in normal animals $(9.98 \pm 1.26 \mathrm{mg} /$ $\mathrm{kg} \cdot \mathrm{min}$ per $\mu \mathrm{U} / \mathrm{ml})$. The metabolic clearance rate of insulin was significantly $(P<0.02)$ reduced in both NPX $(12.1 \pm 0.7$ $\mathrm{ml} / \mathrm{kg} \cdot \mathrm{min})$ and NPX-PTX $(12.1 \pm 0.9 \mathrm{ml} / \mathrm{kg} \cdot \mathrm{min}) \mathrm{dogs}$, as compared with normal animals $(17.4 \pm 1.8 \mathrm{ml} / \mathrm{kg} \cdot \mathrm{min})$. The basal hepatic glucose production was similar in both groups of animals and not different from normal dogs; both the time

Address correspondence to Dr. Massry, Division of Nephrology. Received for publication 2 April 1984 and in revised form 30 October 1984.

J. Clin. Invest.

(c) The American Society for Clinical Investigation, Inc.

0021-9738/85/03/1037/08 \$1.00

Volume 75, March 1985, 1037-1044 course and the magnitude of suppression of hepatic glucose production by insulin were similar in both groups. There were no differences in the binding affinity, binding sites concentration, and binding capacity of monocytes to insulin among NPX, NPX-PTX, and normal dogs.

The data show that $(a)$ glucose intolerance does not develop with CRF in the absence of PTH, (b) PTH does not affect metabolic clearance of insulin or tissue resistance to insulin in CRF, and (c) the normalization of glucose metabolism in CRF in the absence of PTH is due to increased insulin secretion.

The results indicate that excess PTH in CRF interferes with the ability of the $\beta$-cells to augment insulin secretion appropriately in response to the insulin-resistant state.

\section{Introduction}

Impaired carbohydrate metabolism is a common finding in patients with chronic renal failure (1-3). Studies in humans have demonstrated that both insulin resistance $(1,2,4,5)$ and impaired insulin secretion contribute to the pathogenesis of the carbohydrate intolerance. The insulin resistance is almost always present in patients with uremia $(3,5)$ whereas insulin secretion could be normal (6), increased (7), or decreased (2). The normal response of the $\beta$-cells to the presence of insulin resistance is to enhance their secretion of insulin $(8,9)$. If, for any reason, the $\beta$-cells are unable to augment their secretion of insulin appropriately, an impaired glucose tolerance would ensue. Indeed, previous studies have shown that glucose intolerance is usually encountered in uremic patients in whom both impaired tissue sensitivity to insulin and impaired $\beta$-cell secretion of insulin coexist $(3,10)$.

During the past several years, data have been accumulated implicating parathyroid hormone $(\mathrm{PTH})^{1}$ as a uremic toxin (11). Excess PTH has been shown to exert deleterious effects on the central (12-14) and peripheral nervous system $(15,16)$, hematopoietic system (17-20), myocardial function $(21,22)$, and skeletal muscle metabolism $(23,24)$. Certain data suggest that PTH may affect carbohydrate metabolism. Patients with primary hyperparathyroidism may have glucose intolerance $(25,26)$. Elevated plasma insulin levels both in the fasting state and in response to glucose $(25,26)$ as well as insulin resistance (26) have been reported in these patients. In addition, Hruska et al. (27) found that 1-84 PTH augmented hepatic glucose production through increased glycogenolysis and gluconeogenesis, and PTH has been shown in vitro to affect both these processes $(28,29)$, which are responsible for increasing hepatic glucose production. However, Bevilacqua et al. (30) could not demonstrate an effect of PTH on hepatic glucose production in the dog.

1. Abbreviations used in this paper: CRF, chronic renal failure; IVGTT, intravenous glucose intolerance test; $M / I$ ratio, total glucose metabolized divided by the total insulin response; NPX, $5 / 6$ nephrectomy but intact parathyroid glands; NPX-PTX, $5 / 6$ nephrectomy and thyroparathyroidectomy; PTH, parathyroid hormone. 
It is, theoretically, possible that the state of secondary heparathyroidism, which is associated with advanced chronic renal failure $(31,32)$, plays an important role in the genesis of the glucose intolerance of uremia. The present study was designed to examine this question.

\section{Methods}

Female mongrel dogs weighing $18-25 \mathrm{~kg}(21 \pm 0.5$ [SE]) were studied. All dogs were subjected to episiotomy to permit easy access to the bladder for the measurement of creatinine clearance in the awake state. The animals received the same diet that provided $78 \mathrm{~g}$ of protein and $60 \mathrm{~g}$ of fat, $5 \mathrm{~g}$ of calcium, and $3 \mathrm{~g}$ of phosphorus per day (KalKan, Kal Kan Foods Company, Inc., Vernon, CA). Base-line studies included the measurements of the plasma concentrations of sodium, potassium, bicarbonate, calcium, magnesium, phosphorus, and serum PTH and the determination of endogenous creatinine clearance. After these studies, all dogs underwent left subtotal renal infarction by ligation of five of the six branches of the left renal artery, and in half of the dogs, thyroparathyroidectomy was also performed at the same time. The success of the procedure was ascertained by a fall in the plasma concentration of calcium of at least $2 \mathrm{mg} / \mathrm{dl}$. The diet of the thyroparathyroidectomized dogs was supplemented with $1-5 \mathrm{~g}$ of calcium carbonate per day to maintain normocalcemia; these dogs also received standardized thyroid extract in the form of thyroid tablets $(60$ $\mathrm{mg}$ ) (Armour thyroid tablets), three times per week. $3 \mathrm{wk}$ later, all animals were subjected to right nephrectomy. Thus, this protocol provided two groups of dogs with chronic renal failure (CRF): one with intact parathyroid glands (NPX) and the other without parathyroid glands (NPX-PTX). All animals were followed carefully thereafter for several months during which measurements of plasma concentrations of electrolyte and PTH were determined several times and endogenous creatinine clearance was measured every month. We did not encounter difficulty in maintaining the NPX and NPX-PTX and the mortality was $\sim 15 \%$.

Two types of studies were performed as follows:

\section{Intravenous glucose tolerance test (IVGTT)}

This test was done initially before parathyroidectomy and before the induction of CRF in 12 dogs and repeated after 3 mo of CRF in six NPX and six NPX-PTX animals. The IVGTT was performed as follows: after the collection of three base-line blood samples for the determination of plasma glucose and insulin, glucose $(0.5 \mathrm{~g} / \mathrm{kg}$ of body weight given as a solution of $50 \%$ dextrose in water) was infused over 2 min. Blood samples were subsequently obtained at $3,5,10,20,30$, 40,50 , and $60 \mathrm{~min}$ for the measurement of plasma glucose and insulin.

\section{Clamp studies}

In six NPX and in seven NPX-PTX dogs both euglycemic insulin clamp and hyperglycemic clamp studies were performed after $46 \pm 8$ wk (NPX) and after 48 77 wk (NPX-PTX) of chronic uremia. Euglycemic insulin clamp was also done in six normal dogs.

Euglycemic insulin clamp. Tissue sensitivity to insulin was determined with the euglycemic insulin clamp technique as previously described (33). Briefly, after a 120-min control period, a primecontinuous ( $1 \mathrm{mU} / \mathrm{kg}$ of body weight per minute) infusion of crystalline porcine insulin (Eli Lilly \& Co., Indianapolis, IN) was administered for $120 \mathrm{~min}$. The plasma glucose concentration was maintained constant at the basal level by the periodic adjustment of a variable infusion of $20 \%$ glucose. Under these steady-state conditions of constant glycemia, all of the infused glucose is taken up by cells and, when added to the rate of residual hepatic glucose production measured with tritiated glucose, provides a measure of the amount of glucose metabolized by the entire body in response to the infused insulin.

120 min before starting the insulin clamp, three NPX and three NPX-PTX dogs also received a $25 \mu \mathrm{Ci}$ bolus of $\left[3-{ }^{3} \mathrm{H}\right]$ glucose and this was followed by a continuous infusion at the rate of $0.25 \mu \mathrm{Ci} / \mathrm{min}$.
During the 30-min period before beginning the insulin, clamp plasma samples were drawn at 5-min intervals for the determination of tritiated glucose specific activity. During the insulin clamp study, samples for the measurement of tritiated glucose were obtained at 5-15-min intervals.

Hyperglycemic clamp. $\beta$-Cell secretion of insulin was assessed with the hyperglycemic clamp study as previously described (33). The plasma glucose concentration was acutely raised by $125 \mathrm{mg} / \mathrm{dl}$ above the basal level by a priming infusion of intravenous glucose given for 10 min. During the subsequent 110 min the plasma glucose concentration was held constant at the desired goal $(+125 \mathrm{mg} / \mathrm{dl})$ by the periodic adjustment of a variable glucose infusion, based upon the negative feedback principle. Under these steady-state conditions of constant hyperglycemia, the infusion rate of glucose, after correction for urinary glucose losses, provides a measure of the amount of glucose taken up by all the tissues of the body.

During the IVGTT, the rate of decline in plasma concentration (K-g rate \%/min) was calculated by using the 10-40 min plasma glucose values (34). During the hyperglycemic clamp study, the glucose infusion rate (minus urinary glucose losses) was determined by calculating the mean value observed from 20 to $120 \mathrm{~min}$. In that hepatic glucose production is suppressed by over $90 \%$ under these conditions of hyperglycemic hyperinsulinemia, the glucose infusion rate closely approximates the amount of glucose taken up by the entire body. The early plasma insulin response was determined from the mean of values obtained at 2-min intervals during the $0-10$-min period. The late plasma insulin response was determined from the mean of values obtained at 10 -min intervals during the $10-120$-min period. The total insulin response represents the weighed mean of values from 0 to 120 min. The total amount of glucose metabolized (M) divided by the total insulin response (I), provides a measure of tissue sensitivity $(\mathrm{M} / \mathrm{I})$ to the endogenously secreted insulin.

During the insulin clamp study, the glucose infusion rate was calculated at 20 -min intervals. Hepatic glucose production (5) was calculated for the corresponding 20-min intervals. Total glucose uptake was determined by adding the rate of residual hepatic production during each 20-min interval to the glucose infusion rate for the same 20 -min period. The mean of values from 20 to $120 \mathrm{~min}$ was used to calculate total body glucose uptake. The total amount of glucose utilized (20-120 min) divided by the steady-state plasma insulin concentration (20-120 min) provides a measure of tissue sensitivity to the exogenously infused insulin. The metabolic clearance rate of insulin was calculated by dividing the continuous insulin infusion rate $(1 \mathrm{mU} /$ $\mathrm{kg} \cdot \mathrm{min}$ ) by the mean increment above base line in plasma insulin concentration during the 20-120-min period.

Plasma glucose concentration was measured by glucose oxidase method (Glucostat, Beckman Instruments, Inc., Fullerton, CA). Plasma insulin concentration was determined by radioimmunoassay. The concentrations of phosphorus, creatinine, and bicarbonate were determined by autoanalyzer (Technicon Instrument Corp., Tarrytown, NY); those of sodium and potassium were measured with a flame photometer (model 343, Instrumentation Laboratory, Inc., Lexington, MA), of calcium and magnesium with an atomic absorption spectrophotometer model 503 (Perkin-Elmer Corp., Norwalk, CT), and of ionized calcium with an Orion Electrode model SS-20 (Orion Biomedical, Cambridge, MA). PTH was determined with radioimmunoassay using sheep antiserum 478 (kindly supplied by Dr. Claude Arnaud), ${ }^{125}$ I-labeled bovine PTH, and pooled sera from patients with renal failure as a standard. This antibody reacts predominantly with an immunologic determinant in the carboxyl region of PTH, and it will detect both the intact hormone and its carboxy-terminal fragment. The values for this assay in 63 samples from normal subjects ranged from undetectable to 15 $\mu \mathrm{leq} / \mathrm{ml}($ mean $\pm \mathrm{SE}, 7.5 \pm 0.7)$, and PTH was detectable in 33 of 63 (52\%) normal subjects. Elevated blood levels of PTH were found in 60 patients with chronic renal failure. The lower limit of detectability was $1 \mu \mathrm{leq} / \mathrm{ml}$. The assay was validated for measurements of PTH in dog serum by comparing PTH values in two separate assays using both pooled human and pooled canine uremic sera as standards. The 
values for PTH displayed a linear correlation with $r=0.99$ for data from sera of normal dogs and an $r$ of 0.92 for data from sera of uremic dogs. Free thyroxin index is calculated as the product of $T_{3}$ uptake ratio and $T_{4}$. The method for the determination of tritiated glucose specific activity has been described previously (35).

Insulin binding to circulating monocytes was determined as previously described $(36,37)$. Insulin receptor number was calculated from the Scatchard analysis (38) and insulin binding affinity from the De Meyts plots (39).

All data are presented as the mean \pm SE. Statistical comparisons between groups were performed by paired or unpaired analysis where appropriate coefficients of variation were determined with standard procedure.

\section{Results}

Studies with IVGTT. The biochemical data before and after CRF in NPX and NPX-PTX dogs evaluated with IVGTT and with euglycemic and hyperglycemic clamps are given in Table I. The $5 / 6$ nephrectomy resulted in a significant decrease $(P$
$<0.01$ ) in creatinine clearance of $\sim 78 \%$ of base-line value and a significant $(P<0.01)$ rise in serum levels of PTH in NPX dogs. There were no significant differences in the other parameters between the values observed before and after the induction of CRF. Similarly, there were no significant differences between these parameters after the induction of CRF in NPX and NPX-PTX except for the high serum levels of PTH in NPX dogs.

The changes in plasma levels of glucose before and after 3 mo of CRF in NPX and NPX-PTX dogs are shown in Figs. 1 and 2 . Within 3 min after the injection of the glucose load, the plasma concentrations of glucose reached their peak and decreased thereafter. NPX dogs with intact parathyroid glands displayed glucose intolerance with the plasma concentrations of glucose being significantly $(P<0.01)$ higher at $20,30,40$, 50 , and $60 \mathrm{~min}$ than those observed before CRF.

CRF produced a decline in the $\mathrm{K}-\mathrm{g}$ rate in NPX dogs with the mean value after $\mathrm{CRF}(1.23 \pm 0.18 \% / \mathrm{min})$ being significantly

Table I. Biochemical Data Before and After Induction of Uremia

\begin{tabular}{|c|c|c|c|c|c|c|c|c|}
\hline & \multicolumn{4}{|l|}{ IVGTT } & \multicolumn{4}{|l|}{ Clamp studies } \\
\hline & \multicolumn{2}{|l|}{$\begin{array}{l}\text { NPX dogs } \\
(n=6)\end{array}$} & \multicolumn{2}{|c|}{$\begin{array}{l}\text { NPX-PTX dogs } \\
(n=6)\end{array}$} & \multicolumn{2}{|l|}{$\begin{array}{l}\text { NPX dogs } \\
(n=6)\end{array}$} & \multicolumn{2}{|c|}{$\begin{array}{l}\text { NPX-PTX dogs } \\
(n=7)\end{array}$} \\
\hline & B & A & B & A & B & A & B & A \\
\hline $\begin{array}{l}\text { Weight, } k g \\
\text { Duration of }\end{array}$ & $20 \pm 0.6$ & $20 \pm 0.6$ & $20 \pm 0.8$ & $20 \pm 0.8$ & $21 \pm 0.7$ & $21 \pm 0.7$ & $21 \pm 1$ & $20 \pm 0.9$ \\
\hline uremia, $w k$ & 12 & 12 & 12 & 12 & $46 \pm 8$ & $46 \pm 8$ & $48 \pm 7$ & $48 \pm 7$ \\
\hline $\begin{array}{l}\text { Creatinine } \\
\text { clearance, } \\
\mathrm{ml} / \mathrm{min}\end{array}$ & $56 \pm 2$ & $12 \pm 4^{*}$ & $58 \pm 3$ & $13 \pm 3^{*}$ & $58 \pm 2$ & $13 \pm 4^{*}$ & $56 \pm 2$ & $13 \pm 3^{*}$ \\
\hline $\begin{array}{l}\text { Fasting plasma } \\
\text { glucose, } m g / d l\end{array}$ & $96 \pm 7$ & $97 \pm 10$ & $106 \pm 5$ & $97 \pm 3$ & $\begin{array}{l}\text { HC: } 96 \pm 2 \\
\text { EC: } 96 \pm 2\end{array}$ & $\begin{array}{r}95 \pm 2 \\
100 \pm 4\end{array}$ & $\begin{array}{l}93 \pm 1 \\
93 \pm 1\end{array}$ & $\begin{array}{l}95 \pm 3 \\
91 \pm 3\end{array}$ \\
\hline $\begin{array}{l}\text { Fasting plasma } \\
\text { insulin, } \mu U / m l\end{array}$ & $14 \pm 1$ & $25 \pm 2 \ddagger$ & $14 \pm 1$ & $18 \pm 1$ & $\begin{array}{l}\text { HC: } 15 \pm 1 \\
\text { EC: } 15 \pm 1\end{array}$ & $\begin{array}{l}24 \pm 3 \\
26 \pm 4\end{array}$ & $\begin{array}{l}16 \pm 1 \\
16 \pm 1\end{array}$ & $\begin{array}{l}23 \pm 3 \\
25 \pm 4\end{array}$ \\
\hline $\begin{array}{l}\text { Plasma sodium, } \\
\text { meq/liter }\end{array}$ & $149 \pm 1$ & $150 \pm 1$ & $150 \pm 1$ & $149 \pm 1$ & $149 \pm 1$ & $148 \pm 1$ & $149 \pm 1$ & $149 \pm 1$ \\
\hline $\begin{array}{l}\text { Plasma potassium, } \\
\text { meq/liter }\end{array}$ & $4.5 \pm 0.1$ & $4.5 \pm 0.1$ & $4.4 \pm 0.1$ & $4.4 \pm 0.1$ & $4.4 \pm 0.1$ & $4.3 \pm 0.1$ & $4.4 \pm 0.1$ & $4.5 \pm 0.1$ \\
\hline $\begin{array}{l}\text { Plasma bicarbonate } \\
\text { meq/liter }\end{array}$ & $21 \pm 0.6$ & $19 \pm 0.5$ & $21 \pm 0.3$ & $20 \pm 0.4$ & $20 \pm 0.6$ & $19 \pm 0.5$ & $22 \pm 0.5$ & $21 \pm 0.5$ \\
\hline $\begin{array}{l}\text { Plasma total } \\
\text { calcium, } m g / d l\end{array}$ & $10.3 \pm 0.3$ & $9.8 \pm 0.2$ & $10.6 \pm 0.2$ & $9.9 \pm 0.2$ & $10.0 \pm 0.3$ & $9.8 \pm 0.2$ & $10.4 \pm 0.2$ & $10.0 \pm 0.2$ \\
\hline $\begin{array}{l}\text { Plasma ionized } \\
\text { calcium, } m g / d l\end{array}$ & $2.3 \pm 0.04$ & $2.2 \pm 0.1$ & $2.6 \pm 0.1$ & $2.4 \pm 0.1$ & $2.5 \pm 0.1$ & $2.3 \pm 0.1$ & $2.4 \pm 0.1$ & $2.2 \pm 0.1$ \\
\hline $\begin{array}{c}\text { Plasma inorganic } \\
\text { phosphorus }\end{array}$ & & & & & & & & \\
\hline$m g / d l$ & $4.1 \pm 0.3$ & $4.0 \pm 0.6$ & $4.4 \pm 0.2$ & $4.7 \pm 0.2$ & $4.0 \pm 0.2$ & $4.0 \pm 0.3$ & $4.5 \pm 0.3$ & $4.7 \pm 0.2$ \\
\hline Plasma magnesium & & & & & & & & \\
\hline $\begin{array}{c}m g / d l \\
\text { Serum PTH, }\end{array}$ & $1.9 \pm 0.1$ & $2.0 \pm 0.1$ & $1.9 \pm 0.1$ & $2.0 \pm 0.1$ & $1.9 \pm 0.03$ & $2.0 \pm 0.04$ & $1.9 \pm 0.1$ & $2.0 \pm 0.1$ \\
\hline $\begin{array}{c}\mu l e q / m l \\
\text { Serum-free }\end{array}$ & $1.0 \pm 0.5$ & $37 \pm 0.5 \ddagger$ & $1.0 \pm 0.5$ & UD & UD & $36 \pm 0.1 \ddagger$ & $1.1 \pm 0.5$ & UD \\
\hline thyroxine index & $2.0 \pm 0.1$ & $2.0 \pm 0.1$ & $2.0 \pm 0.1$ & $1.9 \pm 0.04$ & $2.0 \pm 0.1$ & $2.0 \pm 0.1$ & $1.9 \pm 0.05$ & $2.0 \pm 0.04$ \\
\hline
\end{tabular}

Data are presented as mean \pm SE. NPX, 5/6 nephrectomy but intact parathyroid glands; NPX-PTX, 5/6 nephrectomy and thyroparathyroidectomy; B, before CRF; A, after CRF; HC, hyperglycemic clamp; EC = euglycemic clamp. ${ }^{*}$ Significant difference $(P<0.01)$ from data obtained before induction of uremia. ‡ Significant difference $(P<0.01)$ between NPX and NPX-PTX after induction of uremia. 


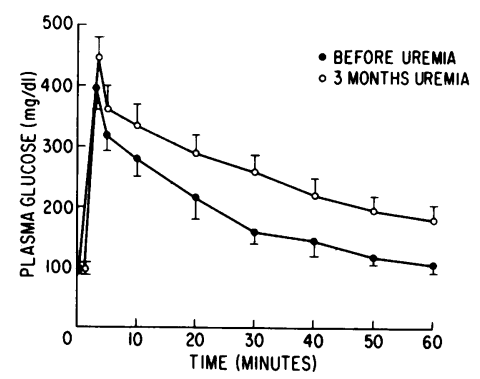

CRF were significantly higher $(P<0.01)$ at $20-60 \mathrm{~min}$
Figure 1. The changes in plasma glucose concentrations during IVGTT performed before (๑) and after (o) 3 mo of CRF in dogs with intact parathyroid glands. Each data point represents the mean value of six dogs and the brackets denote 1 SE. Plasma glucose levels in dogs with

$(P<0.01)$ lower than before CRF $(2.86 \pm 0.48 \% / \mathrm{min})$. However, in NPX-PTX dogs the $\mathrm{K}-\mathrm{g}$ rate was not significantly affected by CRF with the values being $2.41 \pm 0.43 \% / \mathrm{min}$ before and $2.86 \pm 0.86 \% / \mathrm{min}$ after CRF (Fig. 3).

The changes in the plasma concentrations of insulin during IVGTT before and after induction of CRF in NPX and NPXPTX dogs are shown in Fig. 4. There were significant increments in plasma insulin levels in all studies. The changes were similar before CRF and parathyroidectomy but different after CRF in NPX and NPX-PTX dogs. In the NPX dogs, plasma insulin concentrations increased from $24 \pm 2.3 \mu \mathrm{U} / \mathrm{ml}$ to a peak of 105 $\mu \mathrm{U} / \mathrm{ml}(P<0.01)$ and remained elevated throughout the study. In the NPX-PTX animals, the maximum increment in plasma insulin concentration (from $18 \pm 1.2$ to $229 \pm 19.4 \mu \mathrm{U} /$ $\mathrm{ml})$ was more than twice that observed in the NPX dogs $(P$ $<0.01)$; the levels gradually declined but were higher than those in NPX dogs for the first $30 \mathrm{~min}(P<0.01)$ and returned to base-line values by $1 \mathrm{~h}$. These differences in plasma insulin were not due to higher plasma glucose concentrations in NPXPTX dogs, and for any given level of plasma glucose during IVGTT the plasma insulin was higher in NPX-PTX than in NPX animals (Fig. 5).

Studies with hyperglycemic clamp. The fasting plasma glucose concentration was $95 \pm 2 \mathrm{mg} / \mathrm{dl}$ in NPX and $95 \pm 3 \mathrm{mg} /$ dl in NPX-PTX dogs; these concentrations were acutely raised and maintained at $212 \pm 6 \mathrm{mg} / \mathrm{dl}$ and $221 \pm 3 \mathrm{mg} / \mathrm{dl}$, respectively. The stability of plasma glucose concentration during the hyperglycemic clamp is indicated by the small coefficient of variation of $3.7 \pm 0.6 \%$ in NPX and $4.9 \pm 0.7 \%$ in NPX-PTX animals. The total amount of glucose metabolized (20-120min time period) was significantly lower by $38 \%$ in the NPX compared with NPX-PTX group $(6.64 \pm 1.13$ vs. $10.74 \pm 1.10$ $\mathrm{mg} / \mathrm{kg} \cdot \min , P<0.025)$, Fig. 6.

The early, late, and total insulin responses were significantly

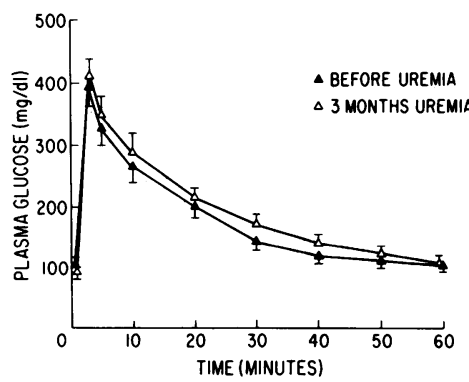

Figure 2. The changes in plasma glucose concentrations during IVGTT performed before ( $\Lambda$ ) and after ( $\triangle) 3 \mathrm{mo}$ of CRF in parathyroidectomized dogs. The studies before CRF were done before parathyroidectomy as well. Each data point represents the mean value of six dogs and the brackets denote $1 \mathrm{SE}$. There were no significant differences in plasma glucose concentration before and after CRF at all times.

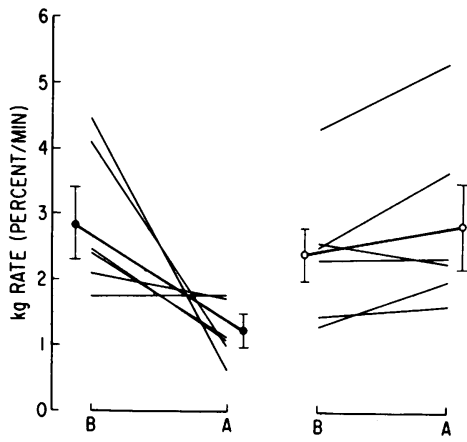

Figure 3. The $\mathrm{K}-\mathrm{g}$ rate before and 3 mo after the CRF in NPX (left) and NPX-PTX (right). $B$ denotes before CRF and $A$ after CRF. Each line represents one animal and the heavy lines depict the mean values with brackets denoting 1 SE. The $\mathrm{K}-\mathrm{g}$ rate after CRF was significantly $(P<0.01)$ lower than before CRF in NPX dogs.

greater in NPX-PTX dogs than in NPX animals. In the early phase (0-10 min) plasma insulin concentration was $91 \pm 7 \mu \mathrm{U} /$ $\mathrm{ml}$ in NPX-PTX and $63 \pm 10 \mu \mathrm{U} / \mathrm{ml}$ in NPX dogs $(P<0.05)$, in the late phase the values were $147 \pm 31$ vs. $72 \pm 9 \mu \mathrm{U} / \mathrm{ml}(P$ $<0.025)$, and the total response gave values of $143 \pm 28$ vs. $71 \pm 10 \mu \mathrm{U} / \mathrm{ml}(P<0.01)$, Fig. 6. There was no significant difference between the $M / I$ ratio in the NPX $(9.9 \pm 2.66 \mathrm{mg} /$ $\mathrm{kg} \cdot \mathrm{min}$ per $\mu \mathrm{U} / \mathrm{ml})$ and NPX-PTX $(8.9 \pm 1.30 \mathrm{mg} / \mathrm{kg}$ min per $\mu \mathrm{U} / \mathrm{ml})$.

Studies with euglycemic insulin clamp. The fasting plasma glucose concentrations in the control, NPX, and NPX-PTX dogs were $102 \pm 3,100 \pm 4$, and $91 \pm 3 \mathrm{mg} / \mathrm{dl}$, respectively. During the insulin clamp, the glucose concentrations were maintained at $97 \pm 3,99 \pm 5$, and $92 \pm 4 \mathrm{mg} / \mathrm{dl}$ with coefficients of variation of $4.0 \pm 0.7,4.2 \pm 0.8$, and $6.8 \pm 1.2 \%$, respectively. The fasting plasma insulin levels were $21 \pm 3 \mu \mathrm{U} / \mathrm{min}$ in control, $26 \pm 4 \mu \mathrm{U} / \mathrm{ml}$ in NPX and $25 \pm 4 \mu \mathrm{U} / \mathrm{ml}$ in NPX-PTX animals; they were raised and maintained (20-120-min period) at $81 \pm 7,110 \pm 4$, and $122 \pm 21 \mu \mathrm{U} / \mathrm{ml}$, respectively (Fig. 7). The metabolic clearance rate of insulin was significantly reduced in both NPX $(12.1 \pm 0.7 \mathrm{ml} / \mathrm{kg} \cdot \mathrm{min}, P<0.02)$ and NPX-PTX $(12.1 \pm 0.9 \mathrm{ml} / \mathrm{kg} \cdot \mathrm{min}, P<0.02)$ dogs as compared with control animals $(17.4 \pm 1.8 \mathrm{ml} / \mathrm{kg} \cdot \mathrm{min})$.

The total amount of glucose metabolized in both NPX $(5.59 \pm 0.71 \mathrm{mg} / \mathrm{kg} \cdot \mathrm{min})$ and NPX-PTX $(5.85 \pm 0.47 \mathrm{mg} /$ $\mathrm{kg} \cdot \mathrm{min}$ ) animals was lower than control dogs $(7.75 \pm 0.74)$ but the difference was not significant (Fig. 7). However, the amount of glucose metabolized per unit time of insulin (M/I ratio), a measure of tissue sensitivity to insulin, was significantly reduced

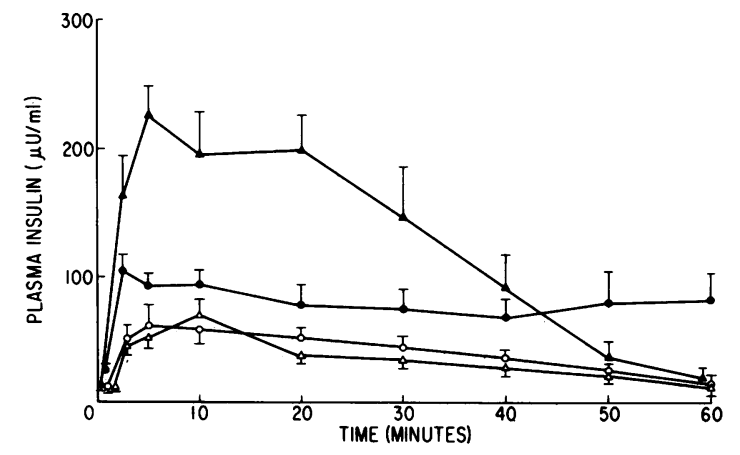

Figure 4. The changes in plasma insulin concentrations during intravenous glucose tolerance tests performed before (open symbols) and after 3 mo of CRF (closed symbols) in NPX (circles) and NPX-PTX (triangles). 


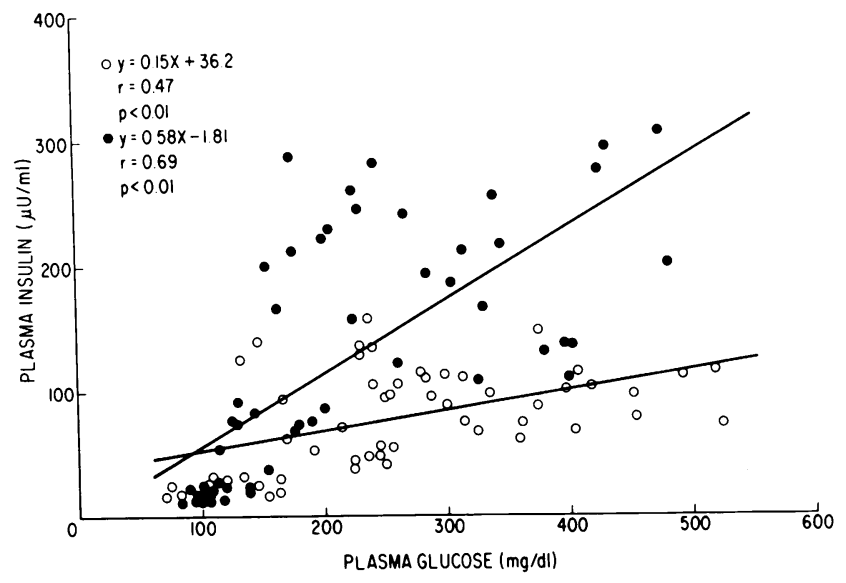

Figure 5. The relationship between plasma insulin and glucose concentrations observed during intravenous glucose tolerance tests performed in NPX (0) and NPX-PTX (•).

both in NPX $(5.12 \pm 0.76 \mathrm{mg} / \mathrm{kg} \cdot \min$ per $\mu \mathrm{U} / \mathrm{ml}, P<0.01)$ and NPX-PTX $(5.18 \pm 0.57 \mathrm{mg} / \mathrm{kg} \cdot \min$ per $\mu \mathrm{U} / \mathrm{ml}, P<0.01)$ animals as compared with control dogs $(9.98 \pm 1.26 \mathrm{mg} / \mathrm{kg} \cdot \mathrm{min}$ per $\mu \mathrm{U} / \mathrm{ml}$ ), Fig. 7.

Basal hepatic glucose production was similar in NPX and NPX-PTX $(2.33 \pm 0.32$ vs. $2.38 \pm 0.35 \mathrm{mg} / \mathrm{kg} \cdot \mathrm{min})$, Fig. 8 . These values are not different from previously reported in normal dogs $(2.80 \pm 0.20 \mathrm{mg} / \mathrm{kg} \cdot \min )(30)$. During the insulin clamp, both the time course and the magnitude of suppression of hepatic glucose production were similar in both groups of animals. During the $20-120$-min period, the hepatic glucose production averaged $0.42 \pm 0.22 \mathrm{mg} / \mathrm{kg} \mathrm{min}$ in NPX dogs and $0.15 \pm 0.07 \mathrm{mg} / \mathrm{kg} \cdot \mathrm{min}$ in NPX-PTX.

Insulin receptors in monocytes. Table II provides the data on binding affinity, binding sites concentration, and binding capacity of monocytes to insulin in NPX, NPX-PTX, and

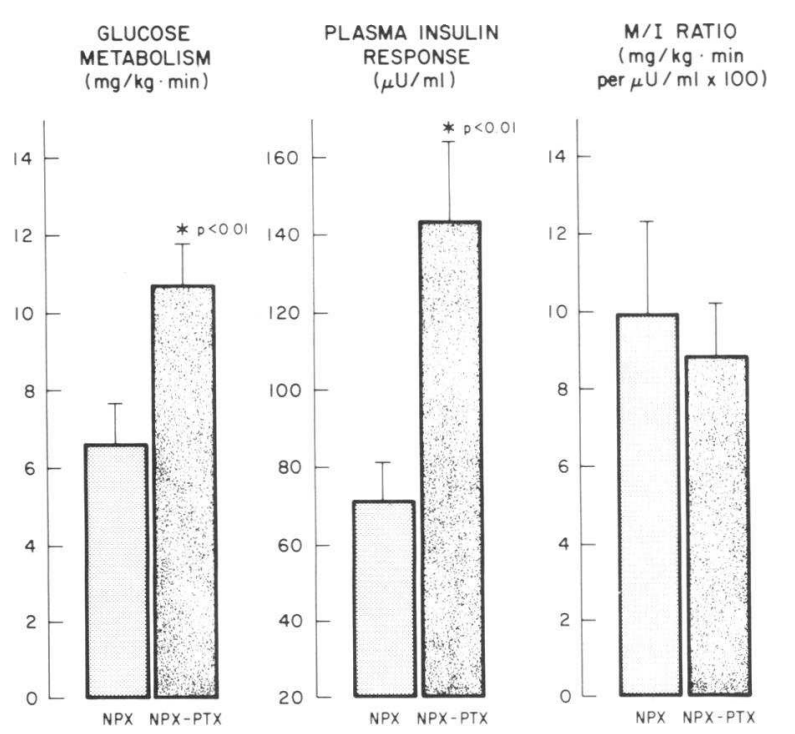

Figure 6. Glucose metabolism, total insulin response, and M/I ratio observed during the hyperglycemic clamp in NPX and NPX-PTX dogs. Each column represents the mean of data from six NPX and seven NPX-PTX dogs. The brackets denote 1 SE. Star indicates significant difference from NPX with $P<0.01$.
EUGLYCEMIC INSULIN CLAMP

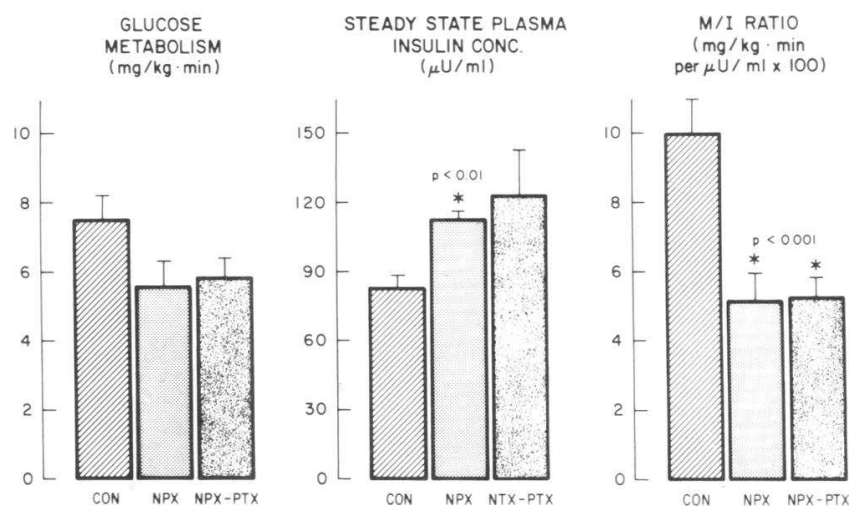

Figure 7. Glucose metabolism, steady-state plasma insulin concentrations, and $M / I$ ratio observed during euglycemic insulin clamp in normal dogs and in NPX and NPX-PTX dogs. Each column represents the mean of data from six NPX and seven NPX-PTX dogs. The brackets denote $1 \mathrm{SE}$. CON = Control. Stars denote significant difference $(P<0.01)$ from control.

control dogs. There were no significant differences in these parameters among the three groups of animals.

\section{Discussion}

The results of the present study demonstrate that the state of secondary hyperparathyroidism of CRF plays a major role in the genesis of the glucose intolerance of uremia. Indeed, a decrease of $>50 \%$ in the glucose disappearance constant during IVGTT and a significantly lower rate of glucose metabolism during the hyperglycemic clamp study were noted in NPX dogs whereas these parameters were normal in NPX-PTX animals.

Available data indicate that the state of glucose intolerance in uremia is due to tissue resistance to insulin (1-5) combined with inability of the $\beta$-cells to appropriately enhance insulin secretion $(3,10)$ to overcome the defect in peripheral glucose removal. The factor(s) responsible for the impairment in insulin action and the inappropriate insulin secretion is (are) not defined. A variety of agents including urea, creatinine, indols, guanidine, polyamines, phenols, Indicans, and various

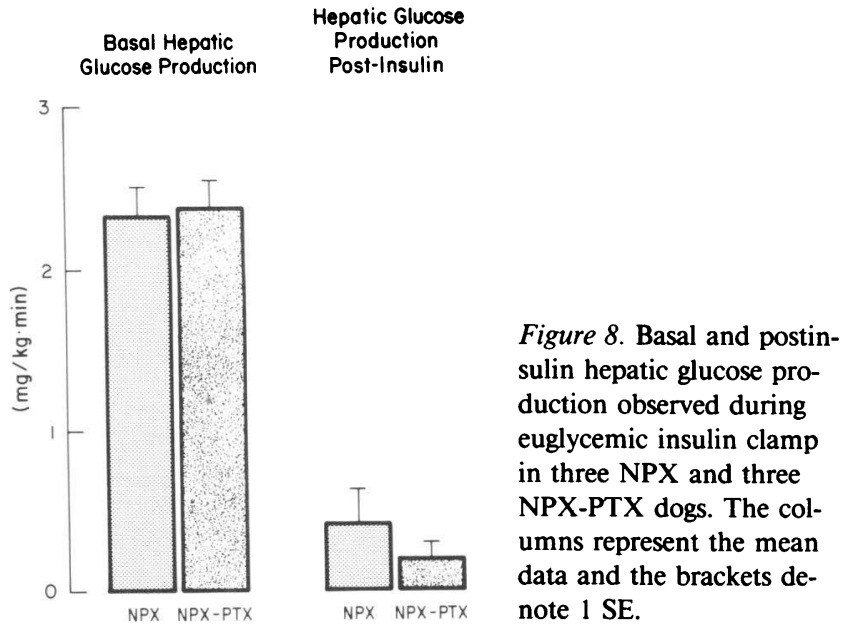


Table II. Insulin Receptors in Monocytes in Control, NPX, and NPX + PTX Dogs

\begin{tabular}{llll}
\hline & Binding \\
affinity $\left(K_{e}\right)$ & $\begin{array}{l}\text { Binding sites } \\
\text { concentration }\end{array}$ & $\begin{array}{l}\text { Binding } \\
\text { capacity } \\
\text { sites/ } \\
\text { monocytes }\end{array}$ \\
\hline & $10^{-9} M$ & $10^{-10} M$ & $10^{4}$ \\
Normal dogs & $4.15 \pm 0.47$ & $1.96 \pm 0.51$ & $1.80 \pm 0.47$ \\
NPX & $5.96 \pm 1.82$ & $2.15 \pm 0.60$ & $1.97 \pm 0.55$ \\
NPX + PTX & $4.28 \pm 0.79$ & $1.76 \pm 0.47$ & $1.61 \pm 0.43$ \\
\hline
\end{tabular}

Each group consists of four animals.

Data are expressed as means \pm SEM.

insulin antagonistic hormones have been implicated in the genesis of glucose intolerance (3) but none has received convincing experimental support. Our data provide evidence that excess PTH is an important pathogenetic factor in the disturbance of carbohydrate metabolism in CRF.

The results of the present study clearly show that excess PTH in CRF does not affect insulin action on peripheral tissues inasmuch as the $\mathrm{M} / \mathrm{I}$ ratio is significantly lower than normal in both NPX and NPX-PTX animals, and there is no significant difference in $\mathrm{M} / \mathrm{I}$ ratio between these two groups of animals (Fig. 7). Further, excess PTH does not seem to affect the possible cellular mechanism or the tissue sites for the impaired insulin action. It has been previously shown that insulin binding to monocytes is normal in patients with advanced renal failure (10), and this finding was interpreted to be consistent with a postreceptor defect in insulin action. The observations in our CRF dogs are in agreement with the findings in CRF subjects and further indicate that excess PTH does not affect the binding of insulin to its receptors. It has also been previously reported that the impairment in insulin action resides in peripheral tissues most likely skeletal muscles (40). In addition, insulin-mediated glucose uptake by the liver as well as suppression of hepatic glucose production by hyperinsulinemia in CRF patients are normal (5). The normal inhibition of hepatic glucose output by hyperinsulinemia in our CRF dogs is consistent with the human observations.

Our data indicate that the normalization of glucose tolerance in NPX-PTX dogs must be due to improvement in insulin secretion by the $\beta$-cells. Several observations in our study support this notion. First, during the IVGTT, the plasma concentrations of insulin in NPX-PTX dogs were twice that noted in NPX animals (Fig. 4), and for any given level of hyperglycemia the plasma insulin concentrations were higher in NPX-PTX than NPX dogs (Fig. 5). Second, the plasma insulin concentrations during the early and late phases of hyperglycemic clamp study as well as the total insulin response were significantly greater in NPX-PTX than NPX animals (Fig. 6). Finally, in that the metabolic clearance rate of insulin was similar in NPX $(12.1 \pm 0.7 \mathrm{ml} / \mathrm{kg} \cdot \mathrm{min})$ and NPX-PTX $(12.1 \pm 0.9 \mathrm{ml} / \mathrm{kg} \cdot \mathrm{min})$ dogs, the higher plasma insulin concentrations in the latter group of animals must have resulted from enhanced insulin secretion and not from decreased insulin removal. It should also be noted that since both the early and late phases of insulin secretion were enhanced by parathyroidectomy, one must assume that the release of both stored as well the newly synthesized insulin is enhanced in the NPXPTX dogs.

The observations of Mak et al. (41) in eight children with CRF before and after medical suppression of the secondary hyperparathyroidism are consistent with our results. They demonstrated that the glucose intolerance in these children disappeared after the normalization of the blood levels of PTH, and this improvement was due to increased insulin response to hyperglycemia after the treatment of the secondary hyperparathyroidism. They concluded that the higher plasma insulin levels overcame the insulin-resistant state, which was not affected by the suppression of the parathyroid gland activity.

Other data appear to differ from ours and those of Mak et al. (41). Amend et al. (42) reported in six dialysis patients that subtotal parathyroidectomy has no effect on glucose utilization, insulin secretion, or insulin sensitivity. These authors studied their patients while they were normocalcemic, hypercalcemic, or hypocalcemic before parathyroidectomy and while hypocalcemic and hypercalcemic after the removal of the parathyroid glands. Since serum calcium levels affect insulin secretion (43, 44), it is difficult to reach a definite conclusion from their data. It would have been helpful if Amend et al. (42) had studied their patients before and after parathyroidectomy while they were maintained normocalcemic. Lindall et al. (45) reported that insulin response to intravenous glucose was significantly increased in dialysis patients with severe secondary hyperparathyroidism and insulin response returned to normal after parathyroidectomy. These authors utilized crude clinical criteria for the assessment of the secondary hyperparathyroidism. They did not provide data on blood levels of PTH or phosphorus; most of their patients were hypocalcemic before parathyroidectomy and they were receiving calcium and vitamin $\mathrm{D}$ after surgery. All these variables make the interpretation of the data difficult. Finally, it should be emphasized that both Amend et al. (42) and Lindall et al. (45) did not utilize the clamp techniques that allow more accurate quantitative measures of carbohydrate metabolism.

Changes in the concentrations of serum phosphorus (46, $47)$, calcium $(43,44)$, magnesium (48), or potassium (49) may affect insulin secretion. The difference in the insulin response to hyperglycemia in our NPX and NPX-PTX dogs could not be attributed to differences in the plasma concentrations of these electrolytes because the levels of the latter were similar in both groups. Also, the effect of parathyroidectomy on plasma insulin concentrations during hyperglycemia is independent of the state of CRF inasmuch as plasma insulin concentrations during IVGTT in chronic normocalcemicnormophosphatemic-thyroparathyroidectomized dogs were twice $(P<0.01)$ the levels observed in normocalcemic dogs with intact parathyroid glands (Fig. 9).

The mechanisms through which excess PTH blunts the insulin response to hyperglycemia are not evident. PTH has been shown to stimulate calcium influx into cells $(18,50,51)$ and an increase in cellular calcium concentration enhances insulin secretion $(52,53)$. It seems, therefore, unlikely that a state of secondary hyperparathyroidism impairs insulin secretion. However, it is possible that the effect of changes in calcium content of the beta cells on insulin secretion depends on the magnitude of the change and on its duration. Such a suggestion is supported by the data of Kanatsuka et al. (54). It seems reasonable to suggest that a state of chronic excess of 

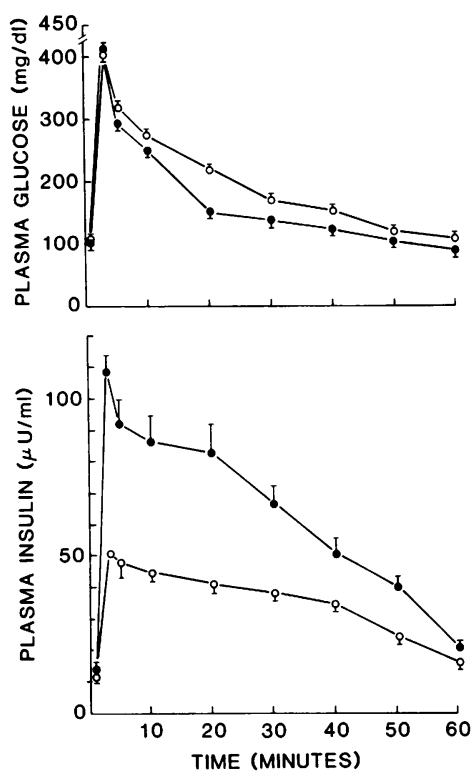

Figure 9. The changes in plasma glucose and insulin concentrations during intravenous glucose tolerance tests performed in six normal dogs (o) and six normocalcemic-normophosphatemic chronic (6 wk) thyroparathyroidectomized dogs with normal renal function (๑). Each data point is the mean of six animals and the brackets denote 1 SE. Plasma insulin levels were significantly higher $(P<0.01)$ at all points between 3 and 50 min.

PTH may cause a marked and sustained elevation in calcium content of the beta cells and such a change may adversely affect the function of these cells. A corollary to a different effect of acute or chronic excess PTH is found in observations in other systems. Excess amount of the hormone acutely stimulates the chronotropic properties of myocardial cells (22) and random motility of polymorphonuclear leukocytes (19), but chronic exposure to the hormone decreases or stops the beating of the heart cells and reduces random motility of the leukocytes. The available data on insulin response to hyperglycemia in patients with primary hyperparathyroidism (a state of chronic excess of PTH) $(25,26)$ do not help resolve these issues in that these patients have hypercalcemia and/or hypophosphatemia, both of which affect insulin release.

It should be mentioned that although our thyroparathyroidectomized dogs received adequate amounts of thyroid hormone, one must be cautious in concluding that the absence of the thyroid gland did not play a role in the increased insulin response in the NPX-PTX dogs. An unidentified thyroid factor(s) presently unknown, and which could not have been replaced by thyroid therapy, may have contributed to our findings.

\section{Acknowledgments}

The authors wish to express their thanks to Ms. Jamie Jimenez for her secretarial assistance in the preparation of this manuscript.

This work was supported by grant AM-29955 from the National Institute of Arthritis, Diabetes, and Digestive and Kidney Disease.

\section{References}

1. Westervelt, F. B., and G. E. Schreiner. 1962. The carbohydrate intolerance of uremic patients. Ann. Intern. Med. 57:266-275.

2. Hampers, C. L., J. S. Soeldoner, P. B. Doak, and J. P. Merrill. 1966. Effect of chronic renal failure and hemodialysis on carbohydrate metabolism. J. Clin. Invest. 45:1719-1731.

3. De Fronzo, R. A., R. Andres, P. Edgar, and W. G. Walker. 1973. Carbohydrate metabolism in uremia: a review. Medicine (Baltimore). 52:469-481.

4. De Fronzo, R. A., J. D. Tobin, J. W. Rowe, and R. Andres. 1978. Glucose intolerance in uremia. Quantification of pancreatic beta cell sensitivity to glucose and tissue sensitivity to insulin. J. Clin. Invest. 62:425-435.

5. De Fronzo, R. A., A. Alverstrand, D. Smith, R. Hendler, E. Hendler, and J. Wahren. 1981. Insulin resistance in uremia. J. Clin. Invest. 67:563-568.

6. Samaan, N. A., and R. M. Freeman. 1970. Growth hormone levels in severe renal failure. Metab. Clin. Exp. 19:102-113.

7. Lowrie, E. G., J. S. Soeldner, C. L. Hampers, and J. P. Merrill. 1970. Glucose metabolism and insulin secretion in uremic, prediabetic, and normal subjects. J. Lab. Clin. Med. 76:603-615.

8. Perley, M., and D. M. Kipnis. 1966. Plasma insulin responses to glucose and tolbutamide of normal weight and obese diabetic and non-diabetic subjects. Diabetes. 15:867-874.

9. Beck, P., D. S. Schalch, M. L. Parker, D. M. Kippnis, and W. H. Daughaday. 1965. Correlative studies of growth hormone and insulin plasma concentrations with metabolic abnormalities in acromegaly. J. Lab. Clin. Med. 66:366-379.

10. De Fronzo, R. A. 1978. Pathogenesis of glucose intolerance in uremia. Metab. Clin. Exp. 27:1866-1880.

11. Massry, S. G. 1983. The toxic effects of parathyroid hormone in uremia. Semin. Nephrol. 3:306-328.

12. Arieff, A. I., and S. G. Massry. 1974. Calcium metabolism of brain in acute renal failure. J. Clin. Invest. 53:387-392.

13. Guisado, R., A. I. Arieff, and S. G. Massry. 1975. Changes in the electroencephalogram in acute uremia. J. Clin. Invest. 55:738-745.

14. Goldstein, D. A., E. I. Feinstein, L. A. Chui, R. Pattabhiraman, and S. G. Massry. 1980. The relationship between the abnormalities in electroencephalogram and blood levels of PTH in dialysis patients. J. Clin. Endocrinol. Metab. 51:130-134.

15. Goldstein, D. A., L. A. Chui, and S. G. Massry. 1978. Effect of parathyroid hormone and uremia on peripheral nerve calcium and motor nerve conduction velocity. J. Clin. Invest. 62:88-93.

16. Avram, M. D., D. A. Feinfeld, and A. H. Huatuco. 1978. Search for the uremic toxin. Decreased motor nerve conduction velocity and elevated parathyroid hormone in uremia. N. Engl. J. Med. 298:1000-1004.

17. Meytes, D., E. Bogin, A. Ma, P. P. Dukes, and S. G. Massry. 1981. Effect of parathyroid hormone on erythropoiesis. J. Clin. Invest. 67:1263-1269.

18. Bogin, E., S. G. Massry, J. Levi, M. Djaldeti, G. Bristol, and J. Smith. 1982. Effect of parathyroid hormone on osmotic fragility of human erythrocyte. J. Clin. Invest. 69:1017-1025.

19. Massry, S. G., C. C. Doherty, P. Kimball, D. Moyer, and N. Brautbar. 1982. Effect of intact parathyroid hormone (PTH) and its aminoterminal fragment on human polymorphonuclear leukocyte: implications in uremia. Proc. Am. Soc. Nephrol. 15:12A. (Abstr.)

20. Remuzzi, G., A. Benigni, P. Dodesini, A. Schieppati, M. Livio, E. Poletti, G. Mecca, and G. DeGaetano. 1982. Parathyroid hormone inhibits human platelet function. Lancet. II:1321-1324.

21. Drueke, T., I. Fleury, Y. Toure, P. De Vernejoul, M. Fauchet, P. Lesourd, C. LePailleur, and J. Crosnier. 1980. Effect of parathyroidectomy on left ventricular function in haemodialysis patients. Lancet. I:112-114.

22. Bogin, E., S. G. Massry, and I. Harary. 1981. Effect of parathyroid hormone on heart cells. J. Clin. Invest. 67:1215-1227.

23. Brautbar, N., R. Baczynski, S. El Belbessi, and S. G. Massry. 1983. Effect of PTH on skeletal muscle. Role of PTH in uremic myopathy. Kidney Int. 23:212. (Abstr.)

24. Garber, A. J. 1983. Effect of parathyroid hormone on skeletal muscle protein and amino acid metabolism in the rat. J. Clin. Invest. 71:806-821.

25. Ginsberg, H., J. M. Olefsky, and G. M. Reaven. 1975. Evaluation of insulin resistance in patients with primary hyperparathyroidism. Proc. Exp. Biol. Med. 148:942-945.

26. Kim, H., R. K. Kalkhoff, N. V. Costrini, J. M. Cerletty, and M. Jacobson. 1971. Plasma insulin disturbances in primary hyperparathyroidism. J. Clin. Invest. 50:2596-2605.

27. Hruska, K. A., J. Blondin, R. Bass, J. Santiago, T. Lorraine, 
P. Altscheler, K. Martin, and S. Klahr. 1979. Effect of intact parathyroid hormone on hepatic glucose release in the dog. J. Clin. Invest. 64: 1016-1023.

28. Moxley, M. A., N. H. Bell, S. R. Wagle, D. O. Allan, and J. Ashmore. 1974. Parathyroid hormone stimulation of glucose and urea production in isolated liver cells. Am. J. Physiol. 227:1058-1061.

29. Hems, D. A., C. S. Harmon, and P. D. Whitton. 1975. Inhibition by parathyroid hormone of glycogen synthesis in the perfused liver. FEBS (Fed. Eur. Biochem. Soc.) Lett. 58:167.

30. Bevilacqua, S., E. Barrett, E. Farranini, R. Gusberg, A. Stewart, L. Richardson, D. Smith, and R. DeFronzo. 1981. Lack of effect of parathyroid hormone on hepatic glucose metabolism in the dog. Metab. Clin. Exp. 30:469-475.

31. Roth, S. I., and R. B. Marshall. 1969. Pathology and ultrastructure of the human parathyroid glands in chronic renal failure. Arch. Intern. Med. 124:390-407.

32. Berson, S. A., and R. Yalow. 1966. Parathyroid hormone in plasma in adenomatous hyperparathyroidism, uremia, and bronchogenic carcinoma. Science (Wash. DC). 154:907-909.

33. De Fronzo, R. A., J. D. Tobin, and R. Andres. 1979. Glucose clamp technique: a method for quantifying insulin secretion and resistance. Am. J. Physiol. 237:E214-E223.

34. Lundbaek, K. 1962. Intravenous glucose tolerance as a tool in definition and diagnosis of diabetes mellitus. Br. Med. J. 1:1507-1513.

35. De Fronzo, R. A., V. Soman, R. S. Sherwin, R. Hendler, and P. Felig. 1978. Insulin binding to monocytes and insulin action in human obesity, starvation and refeeding. J. Clin. Invest. 62:204-213.

36. Boyum, A. 1968. Separation of leucocytes from blood and bone marrow. Scand. J. Clin. Invest. 21(Suppl. 97):77-89.

37. Beck-Nielsen, H., O. Pedersen, K. Kragballe, and N. SchwartzSorensen. 1977. The monocyte as a model for the study of insulin receptor in man. Diabetologia. 13:563-569.

38. Scatchard, G. 1949. The attractions of proteins for small molecules and ions. Ann. N.Y. Acad. Sci. 51:660-672.

39. De Meyts, P., and J. Roth. 1975. Cooperativity in Ligand binding: A new graphical analysis. Biochem. Biophys. Res. Commun. 66:1118-1126.

40. Mondon, C. E., C. B. Dolkas, and G. M. Reaven. 1978. The site of insulin resistance in acute uremia. Diabetes. 27:571-576.

41. Mak, R. H., C. Turner, G. B. Haycock, and C. Chantler. 1984. Secondary hyperparathyroidism and glucose intolerance in children with uremia. Kidney Int. 24:S123-S133.
42. Amend, W. J. C., Jr., S. M. Steinberg, E. G. Lowrie, J. M. Lazarus, J. S. Soeldner, C. L. Hampers, and J. P. Merrill. 1975. The influence of serum calcium and parathyroid hormone upon glucose metabolism in uremia. J. Lab. Clin. Med. 86:435-444.

43. Littledike, E. T., D. A. Witzel, and S. C. Whipp. 1968. Insulin: Evidence for inhibition of release in spontaneous hypocalcemia. Proc. Soc. Exp. Biol. Med. 129:135-139.

44. Yasudo, K., Y. Hurukawa, M. Oruyama, M. Kikuchi, and K. Yoshinaga. 1975. Glucose tolerance and insulin secretion in patients with parathyroid disorders. Effect of serum calcium on insulin release. N. Engl. J. Med. 292:501-504.

45. Lindall, A., R. Carmena, S. Cohen, and C. Compty. 1971. Insulin hypersecretion in patients on chronic hemodialysis. Role of parathyroids. J. Clin. Endocrinol. 32:653-658.

46. Harter, H. H., J. V. Santiago, W. E. Rutherford, E. Slatopolsky, and S. Klahr. 1967. The relative role of calcium, phosphorus, and parathyroid hormone in glucose- and tolbutamide-mediated insulin release. J. Clin. Invest. 56:359-367.

47. Campillo, J. E., J. I. Osuna, M. T. Pages, A. Blazquez, M. Castillo, and C. Osario. 1981. Effect of inorganic phosphate on basal and glucose-induced insulin release in vitro. Influence of magnesium concentration. Diabetologia. 21:256-286.

48. Kahil, M. E., J. E. Parrish, E. L. Simons, and H. Brown. 1966. Magnesium deficiency and carbohydrate metabolism. Diabetes. 15: 734-739.

49. Gardner, L. I., B. Nathan, M. D. Talbot, C. D. Cook, H. Berman, and C. R. Uribe. 1950. The effect of potassium deficiency on carbohydrate metabolism. J. Lab. Clin. Med. 35:592-602.

50. Chausmer, A. B., B. S. Sherman, and S. Wallach. 1972. The effect of parathyroid hormone on hepatic cell transport of calcium. Endocrinology. 90:663-672.

51. Borle, A. B. 1973. Calcium metabolism at cellular level. Fed. Proc. 30:1944-1950.

52. Gerich, J. E., M. A. Charles, and G. M. Grodsky. 1976. Regulation of pancreatic insulin and glucagon secretion. Annu. Rev. Physiol. 38:353-388.

53. Hedeskov, C. J. 1980. Mechanism of glucose-induced insulin secretion. Physiol. Rev. 60:442-509.

54. Kanatsuka, A., H. Makino, Y. Matsushima, J. Kasanuki, M. Osegawa, and A. Kumagai. 1981. Effect of calcium on the secretion of somatostatin and insulin from pancreatic islets. Endocrinology. 108: 2254-2257. 